Meissner Andrzej

(Rzeszów)

\title{
Historia wychowania w Uniwersytecie Rzeszowskim w latach 1981-2006
}

Dokonania naukowe rzeszowskich historyków wychowania zostały zaprezentowane w krótkiej notatce zamieszczonej w „Biuletynie Historii Wychowania” (1996) oraz w obszerniejszym artykule opublikowanym w pracy zbiorowej pt. Historia wychowania $w$ XX wieku (1998) ${ }^{1}$. Nawiązując raz jeszcze do tych publikacji należy przypomnieć, że intensyfikacja badań w omawianej dziedzinie nastąpiła po 1980 , tj. po utworzeniu Zakładu Andragogiki i Historii Wychowania (1981), której kierownikiem został dr Andrzej Janczur. Samodzielny Zakład Historii Wychowania został utworzony dopiero w 1984, po uzyskaniu habilitacji przez Andrzeja Meissnera. Skład zakładu stanowili dr hab. Andrzej Meissner (kierownik), dr Jerzy Potoczny (doktorat 1984), dr Czesław Płaza (doktorat $1994)^{2}$, dr Adam Horbowski (doktorat 1978) ${ }^{3}$, mgr Władysława Szulakiewicz (doktorat 1992), mgr Edward Kołek ( w latach 90. przeszedł na emeryturę), mgr Adam Krzanowski (w Zakładzie od 1987) i mgr Kazimierz Szmyd (w Zakładzie od 1991, doktorat 1994). Od 1985 do 1990 w skład Zakładu wchodził prof. Józef Grzywna, który pełnił w tym czasie funkcję dyrektora Instytutu Pedagogiki WSP. W latach 80. zajęcia dydaktyczne prowadził okresowo prof. Adam Massalski. Dla rozwoju Zakładu ważne znaczenie miała współpraca z krakowskim ośrodkiem naukowym, tj. z Wyższą Szkołą Pedagogiczną i Uniwersytetem Jagiellońskim. Dzięki tym kontaktom Zakład Historii Wychowania pozyskał na pełny etat prof. Czesława Majorka (1991-2002), a następnie prof. Juliana Dybca (2002-2005). Z kolei współpraca nawiązana z Uniwersytetem Przykarpackim w Iwanofrankiwsku (Stanisławów) na Ukrainie umożliwiła zatrudnienie prof. Bogdana Stuparika (1995-2002). Listę tę należy uzupełnić nazwiskiem prof. Jana Szmyda (WSP Kraków) i prof. Piotra Szydłowskiego (WSP Kraków), którzy wprawdzie reprezentowali nauki filozoficzne, ale swoje zainteresowania naukowe koncentrowali również wokół problemów historii nauki i kultury oraz antropologii, dzięki czemu wspierali działalność dydaktyczną Zakładu prowadząc seminaria magisterskie. Bezpośrednia współpraca z wy-

\footnotetext{
${ }^{1}$ W. Szulakiewicz, Historia wychowania w Wyższej Szkole Pedagogicznej w Rzeszowie, „Biuletyn Wychowania 1996, nr 1-2, s. 47-48; E. Barnaś, A., Horbowski, Badania historyczno-pedagogiczne w rzeszowskim ośrodku naukowym, w: Historia wychowania w XX wieku. Dorobek i perspektywy, red. T. Gumuła i inni, Kielce 1998, s.563-568.

${ }^{2} \mathrm{Cz}$. Plaza zajmował się najnowszą historią oświaty i obronił pracę doktorską na WSP w Krakowie na temat „Działalność Powszechnej Organizacji „Służba Polsce” w woj. rzeszowskim w latach 1948-1955”.

${ }^{3}$ A. Horbowski obronił pracę doktorską na Uniwersytecie Jagiellońskim na temat „Społeczne funkcje regionalnych towarzystw kulturalnych".
} 
mienionymi uczelniami otworzyła drogę pracownikom Zakładu do podjęcia działalności naukowej, zakończonej stopniami doktorskimi i habilitacjami. Należy tu wymienić J. Potocznego i K. Szmyda, którzy u prof. Cz. Majorka obronili prace doktorskie. Pierwszy $\mathrm{z}$ nich zajął się elementarną oświatą dorosłych w Galicji, drugi pisał o poglądach pedagogicznych Zygmunta Mysłakowskiego. Kolejny doktorat związany z dziejami myśli pedagogicznej w Galicji został poświęcony Władysławowi Seredyńskiemu przedstawicielowi nauk pedagogicznych i nauczycielowi pedagogiki w seminariach nauczycielskich w Krakowie i Tarnowie. Dysertacja ta napisana przez mgr W. Szulakiewicz pod kierunkiem A. Meissnera została obroniona na Uniwersytecie Wrocławskim w 1992 r. Wszystkie trzy prace doktorskie ukazały się drukiem w Wydawnictwie WSP w Rzeszowie ${ }^{4}$. Z kolei B. Stuparik stworzył możliwość dr J. Potocznemu otwarcia przewodu habilitacyjnego na Uniwersytecie Kijowskim na podstawie monografi pt. Oświata dorostych i popularyzacja wiedzy w plebejskich środowiskach Galicji doby autonomicznej (1967-1918), która ukazała się w serii wydawniczej Galicja i jej dziedzictwo (T. 10). Pracę nad habilitacją podjął również K. Szmyd, który przygotował obszerną monografię poświęconą kształtowaniu się lwowskiego ośrodka nauk pedagogicznych $\mathbf{w}$ XIX w. i XX w. (do wybuchu II wojny światowej). Praca ta pt. Twórcy nauk o wychowaniu w środowisku akademickim Lwowa (1860-1939), (Rzeszów 2003), została obroniona na Uniwersytecie Warszawskim w 2005 r. Do tego nurtu badań nad dziejami oświaty Galicji włączyły się również doktorantki A. Meissnera: Ewa Barnaś-Baran, która w Akademii Pedagogicznej w Krakowie w 2005 r. obroniła pracę poświęconą „Krakowskiemu Towarzystwu Dobroczynności w latach 1816-1918" i Elżbieta Dolata, która przygotowała pracę na temat „Ruch higieniczny w szkole galicyjskiej. Postulaty teoretyczne i próby realizacji"'5. Należy wspomnieć, że z Zakładem Historii wychowania współpracował dr Wojciech Motyka (Zakład Pedagogiki Wczesnoszkolnej i Przedszkolnej Instytutu Pedagogiki UR), który zajął się nauczaniem muzyki w galicyjskich szkołach ludowych, zaś mgr Barbara Lubojemska (nauczycielka szkół średnich) przygotowała pracę doktorską o nauczaniu języka polskiego w galicyjskich szkołach ludowych.

Dokonany przegląd badań związany z uzyskiwaniem stopni naukowych stanowi interesujący przykład koncentrowania się zainteresowań naukowych pracowników Zakładu wokół szeroko rozumianych dziejów oświaty i myśli edukacyjnej w zaborze austriackim, a więc w tzw. Galicji, która po uzyskaniu autonomii stała się ośrodkiem polskiej oświaty, życia naukowego i kulturalnego. Fakt ten miał istotne znaczenie dla procesu kształtowania się profilu dalszych badań zorientowanych na problematykę oświaty w XIX w., dzięki czemu Rzeszów obok Krakowa, Wrocławia i innych miast stał się ośrodkiem badań historyczno-pedagogicznych nad dziejami XIX-wiecznej edukacji w tej części ziem polskich, które pozostawały pod obcym panowaniem. W ten sposób rzeszowscy historycy wychowania starali się nawiązać do przedwojennej działalności naukowej Komisji do

\footnotetext{
${ }^{4}$ J. Potoczny, Rozwój elementarnej oświaty dorostych w Galicji doby autonomicznej 1967-1918, Rzeszów 1988; W. Szulakiewicz, Wiadystaw Seredyński. Studium z dziejów pedagogiki galicyjskiej, Rzeszów 1995. Seria Galicja i jej dziedzictwo, T. 7; K. Szmyd, Zygmunt Karol Mystakowski (1890-1971), twórczość $i$ wkład do rozwoju nauk o wychowaniu, Rzeszów 1997.

${ }^{5}$ Obrona pracy odbyła się w Akademii Pedagogicznej w Krakowie w 2007 r.
} 
Badania Dziejów Wychowania i Szkolnictwa, z siedzibą w Krakowie i jego oddziałem we Lwowie. Głównym celem Komisji było właśnie podjęcie badań nad dziejami oświaty w Galicji, co jednak nie zostało zrealizowane, tym bardziej, że w 1929 r. Komisja została rozwiązana. Po II wojnie światowej badania nad Galicją zostały na nowo podjęte, lecz bazowano wyłącznie na źródłach krajowych, gdyż archiwa lwowskie, zawierające najważniejszy zasób materiałów do dziejów galicyjskiej oświaty, były w zasadzie niedostępne. Dalsze zatem badania nad w/w problematyką nie mogły być już kontynuowane bez sięgnięcia do tych właśnie zasobów archiwalnych. Ten kierunek badań historyczno-pedagogicznych został przyjęty przez środowisko historyków WSP w Rzeszowie i to zarówno w odniesieniu do badań podejmowanych indywidualnie, jak i prac zespołowych. Stąd częste wyjazdy do Centralnego Państwowego Archiwum Historycznego i Państwowego Archiwum Obwodowego we Lwowie, w których mnajdują się akta Namiestnictwa, Rady Szkolnej Krajowej, towarzystw i organizacji kulturalno-oświatowych, akta szkół poszczególnych szczebli kształcenia, w tym przede wszystkim Uniwersytetu Lwowskiego, akta placówek opieki nad dzieckiem itp. ${ }^{6}$

Warto podkreślić, że rzeszowskim historykom wychowania udało się wyjść poza indywidualne zainteresowania badawcze i podjąć prace zespołowe, stanowiące pogłębienie i poszerzenie dotychczasowych badań. W 1988 r. przy współpracy dr Stefana Możdżenia z Wyższej Szkoły Pedagogicznej w Kielcach została pojęta praca nad Bibliografia dziejów oświaty $i$ wychowania w Galicji 1772-1918 (Rzeszów 1992), w której zarejestrowano około 3 tysięcy opracowań. Jej kontynuacją jest część druga przygotowana przy współpracy prof. J. Dybca z Uniwersytetu Jagiellońskiego, zawierająca wykaz źródeł drukowanych do dziejów Galicji, w której zarejestrowano około 5 tysięcy pozycji zawierających następujące kategorie źródeł: wydawnictwa o charakterze normatywnym, źródła statystyczne, plany i programy nauczania do poszczególnych kategorii szkół, podręczniki, przewodniki i opracowania metodyczne, sprawozdania administracji szkolnej i placówek oświatowych, źródła do dziejów oświaty pozaszkolnej, projekty reform szkolnych, prace reprezentujące galicyjską myśl pedagogiczną. Praca ukazała się nakładem Wydawnictwa Uczelnianego Uniwersytetu Rzeszowskiego na początku 2007 r. Kolejną pracą zespołową zainicjowaną przez prof. A. Meissnera jest słownik polskich historyków wychowania opracowany przy współudziale prof. W. Szulakiewicz z UMK w Toruniu. W opracowaniu słownika wzięła udział większość ośrodków akademickich w Polsce. Po dyskusjach przeprowadzonych na konferencji historyków wychowania, która została zorganizowana przez WSP w Kielcach w 1997 r. oraz na posiedzeniach ZG Towarzystwa Historii Edukacji, publikacja otrzymała ostateczny tytuł Słownik biograficzny polskiej historii wychowania i zostanie wydana pod patronatem THE. Z kolei Koło THE działające przy Zakładzie Historii Wychowania w Rzeszowie zainicjowało kolejną pracę zbiorową poświęconą przedstawicielom nauki historii oświaty, nauki i kultury Rzeszowszczyzny XIX i XX w.

Do oddzielnej grupy prac badawczych o charakterze zespołowym należy zaliczyć organizowanie cyklicznych konferencji ogólnopolskich i międzynarodowych poświęconych dziejom oświaty w Galicji. Pierwsza taka konferencja odbyła się w 2 lata po utwo-

\footnotetext{
${ }^{6}$ A. Meissner, J. Potoczny, Źródta do dziejów oświaty galicyjskiej w zbiorach Centralnego Archiwum Historycznego Państwowego we Lwowie, „Przegląd Historyczno-Oświatowy” 1989, nr 4, s. 495-499.
} 
rzeniu Zakładu Historii Wychowania, a więc w 1986 r. i poświecona była przeglądowi badań nad podstawowymi dziedzinami życia oświatowego w Galicji i ustaleniu potrzeb badawczych $w$ tym zakresie. Punktem odniesienia $w$ tych rozwaźaniach był artykuł R. Dutkowej pt. Oświata $i$ wychowanie $w$ Galicji $w$ polskiej historiografii ostatniego czterdziestolecia (1945-1985), („Przegląd Historyczno-Oświatowy” 1986, nr 4) ${ }^{7}$. Bodźcem do organizowania dalszych tego typu konferencji stała się opinia wyrażona przez K. Mrozowską, która recenzując materiały pokonferencyjne stwierdziła, że „potrzeba takich spotkań jest oczywista, a zaprezentowane wypowiedzi dowodzą, jak potrzebne są dalsze prace, bardziej zintegrowane i pogłębione"8. Okazją do dalszego zajęcia się problematyką galicyjską stała się inicjatywa, podjęta przez prof. Kazimierza Sowę, ówczesnego rektora WSP w Rzeszowie, zorganizowania międzynarodowej konferencji poświęconej Galicji, będącej wielkim złożonym problemem historycznym i ciągle jeszcze żywym mitem. Tytuł konferencji "Galicja i jej dziedzictwo" mogący budzić pewne kontrowersje uzasadnił K. Sowa, powołując się m.in. na opinię prof. Józefa Buszki, stwierdzając, że „większość nowoczesnych instytucji życia publicznego odrodzone Państwo Polskie zawdzięczało właśnie Galicji. Była więc ona nie tylko skarbnicą narodowej kultury, lecz także kolebką nowoczesnej państwowości polskiej"9. Zakład włączył się do tych prac, przewodniczono obradom sekcji poświęconej nauce i oświacie galicyjskiej, i zredagowano trzeci tomu tego wydawnictwa ${ }^{10}$. Konferencja dała początek serii wydawniczej, wydawanej pod tym samym tytułem, $\mathrm{z}$ której cztery pierwsze tomy stanowiły pokłosie wspomnianej konferencji. Nawiązując do podjętych dotąd inicjatyw Zakład Historii wychowania zorganizował w 1995 r. kolejną międzynarodową konferencję poświęconą galicyjskiej myśli edukacyjnej. Problematyka konferencji objęła cztery grupy zagadnień: początki pedagogiki jako nauki, rozwój myśli pedagogicznej, rola czasopism pedagogicznych w upowszechnianiu prądów pedagogicznych i osiągnięć nauk pedagogicznych oraz wybrane zagadnienia pedagogiki instytucjonalnej ${ }^{11}$. W czasie obrad zwrócono uwagę na potrzebę podjęcia badań przede wszystkim o charakterze porównawczym nad myślą edukacyjną tego okresu, a także ukazania różnojęzycznych czasopism pedagogicznych wychodzących w Galicji i ich roli w rozwoju myśli pedagogicznej. Kolejna konferencja o charakterze międzynarodowym odbyła się w 1998 r. i poświęcona została pedagogice „Nowego Wychowania”, które odegrało znaczącą rolę w przebudowie oświaty. Znaczna część referatów odnosiła się do terenu Galicji i dotyczyła poglądów Henryka Rowida, roli galicyjskich czasopism pedagogicznych w upowszechnianiu idei „Nowego Wychowania", a także innowacyjnej działalności szkół i instytucji pozaszkolnych. W czasie obrad odsłonięto w budynku byłego seminarium nauczycielskiego w Rzeszowie

\footnotetext{
${ }^{7}$ Materiały z sesji ukazały się pt. $Z$ dziejów aświaty w Galicji, red. A. Meissner, Rzeszów 1989.

${ }^{8}$ K. Mrozowska, $Z$ dziejów oświaty w Galicji, red. A. Meissner, Rzeszów 1989, „Przegląd Historyczno-Oświatowy, 1991, nr 1-2, s. 118-120.

${ }^{9}$ K. Sowa, Stowo wstepne, w: „Galicja i jej dziedzictwo”, T. 1: Historia i polityka, red. W. Bonusiak, J. Buszko, Rzeszów 1994, s. 6.

${ }^{10}$ Galicja i jej dziedzictwo, T. 3: Nauka i Oświata, red. A. Meissner, J. Wyrozumski, Rzeszów 1995.

${ }^{11}$ Materiały z ten sesji ukazały się w wydawnictwie pt. „Galicja i jej dziedzictwo”, T. 8: Myśl pedagogiczna w Galicji 1772-1918, Ciqgłość i zmiana, red. Cz. Majorek, A. Meissner, Rzeszów 1996.
} 
tablicę pamiątkową poświęconą $H$. Rowidowi, który był wychowankiem tego Zakładu kształcenia nauczycieli i tutaj uzyskał uprawnienia nauczycielskie ${ }^{12}$. Ostatnia z serii konferencji galicyjskich miała miejsce w 2006 r. i nosiła tytuł „System oświaty w Galicji 1772-1918 i jego rola w przemianach cywilizacyjnych". Przygotowana wspólnie z Zakładem Oświaty i Kultury Uniwersytetu Jagiellońskiego zgromadziła historyków i historyków wychowania Polski, Ukrainy i Słowacji. Problematyka obrad obejmowała kilka bloków tematycznych ukazujących rozwój i rolę, jaką odegrało w przemianach społecznych szkolnictwo ludowe średnie, zawodowe oraz szkoły wyższe. Ziemie zaboru austriackiego zostały ukazane jako teren działalności organizacji i towarzystw kulturalno-oświatowych i dobroczynnych, dzięki którym możliwe było zaspokajanie podstawowych potrzeb życia społecznego, także rozwój życia kulturalnego. Oddzielne miejsce zajęły problemy szkolnictwa żydowskiego, ukraińskiego i ich roli w kształtowaniu świadomości narodowej tych społeczności. Wygłoszone referaty dały więc możliwość ukazania różnorodnych funkcji oświaty, ulegającej stopniowej ewolucji, stając się ważnym czynnikiem przemian cywilizacyjnych, które w Galicji przybrały na sile na przełomie XIX i XX w.

A oto jak przedstawia się udział Zakładu Historii Wychowania w wydawnictwie seryjnym „Galicja i jej dziedzictwo" obejmującym obecnie 19 tomów.

1. Tom 3 Nauka i oświata, red. A. Meissner i J. Wyrozumski, Rzeszów 1995. Materiały pokonferencyjne.

2. Tom 6 Nauczyciele galicyjscy. Udzial polskich nauczycieli galicyjskich $w$ rozwoju teorii pedagogicznej i badań naukowych 1860-1918, red. A. Meissner, Rzeszów 1996. Praca zbiorowa.

3. Tom 7 W. Szulakiewicz, W. Seredyński, Studium z dziejów pedagogiki galicyjskiej, Rzeszów 1995. Praca doktorska.

4. Tom 8 Myśl pedagogiczna w Galicji 1772-1918, Ciagtość i zmiana, red. Cz. Majorek, A. Meissner, Rzeszów 1996. Materiały pokonferencyjne.

5. Tom 9 Biografie pedagogiczne. Szkice do portretu galicyjskiej pedagogii, red. Cz. Majorek i J. Potoczny, Rzeszów 1997. Praca zbiorowa.

6. Tom 10 J. Potoczny, Oświata dorostych i popularyzacja wiedzy w plebejskich środowiskach Galicji doby konstytucyjnej (1967-1918), Rzeszów 1998. Praca habilitacyjna.

7. Tom 11 A. Meissner, Spór o duszę polskiego nauczyciela. Społeczeństwo galicyjskie wobec problemów kształcenia nauczycieli, Rzeszów 1999. Monografia.

8. Tom 14 Pedagogika Nowego Wychowania w Polsce u schylku XIX w. $i$ w pierwszej polowie XX wieku. Podstawowe przejawy $i$ wspótczesne odniesienia, red.

A. Meissner, Cz. Majorek, Rzeszów 2000. Materiały pokonferencyjne.

9. Tom 16 Opieka nad dzieckiem w Galicji, red. A. Meissner, Rzeszów 2002. Praca zbiorowa.

10. Tom 20 W przygotowaniu materiały z konferencji naukowej „System oświaty w Galicji 1772-1918 i jego rola w przemianach cywilizacyjnych".

\footnotetext{
${ }^{12}$ Materiały z tej konferencji ukazały się w wydawnictwie pt. „Galicja i jej dziedzictwo”, T. 14: Pedagogika Nowego Wychowania w Polsce u schylku LXI w. i w pierwszej potowie XX wieku. Podstawowe przejawy $i$ wspótczesne odniesienia, red. A. Meissner, Cz. Majorek, Rzeszów 2000.
} 
Obok konferencji poświęconych tematyce galicyjskiej Zakład Historii Wychowania partycypował w kilku innych tego typu przedsięwzięciach naukowych. W 1995 r. odbył się w Rzeszowie I Kongres Historyków Wsi i Ruchu Ludowego zorganizowany przez rzeszowską WSP. Jedną z sekcji poświęconej kulturze i oświacie wiejskiej kierował A. Meissner, zaś kilku pracowników zakładu wygłosiło stosowne referaty (A. Meissner, Cz. Majorek, J. Potoczny J. Szmyd, W. Szulakiewicz) ${ }^{13}$. Z kolei w 1997 z inicjatywy ówczesnej dyrekcji Instytutu Pedagogiki w Rzeszowie została nawiązana współpraca z Seminarium Duchownym w Rzeszowie, która zaowocowała dwiema konferencjami. Pierwsza odbyła się w budynku WSP w 1997 r., druga w Seminarium Duchownym w 1998 r. Pierwsza poświęcona była ks. Bronisławowi Markiewiczowi i jego koncepcji opieki nad dziećmi i młodzieżą, którą tworzył i realizował na przełomie XIX i XX w. w Miejscu Piastowym niedaleko Krosna ${ }^{14}$. Następne spotkanie związane było wprawdzie ze współczesnymi problemami opieki nad dzieckiem, niemniej zostały uwzględnione aspekty historyczne, czego przykładem jest referat A. Meissnera, „Przedstawiciele pedagogiki świeckiej i kościelnej wobec problemów dziecka na przykładzie Galicji doby autonomicznej"15.

Nie sposób wymienić udziału rzeszowskich historyków wychowania w konferencjach organizowanych przez inne ośrodki naukowe w Polsce i za graniç̨. Warto przynajmniej wymienić rocznicowe spotkania historyków wychowania. I tak np. w Bratysławie odbyła się kolejna konferencja komeniologiczna z okazji 330 rocznicy śmierci wielkiego pedagoga, w której wzięli udział J. Potoczny i A. Meissner ${ }^{16}$. Z kolei w 2003 r. Regionalne Stowarzyszenie im. Stanisława Konarskiego w Ostrowcu Świętokrzyskim zorganizowało spotkanie naukowe z okazji 230 r. śmierci S. Konarskiego, w którym wzięli również udział pracownicy naukowi z Rzeszowa ${ }^{17}$. W 2006 r. przypadła 180 rocznica śmierci Stanisława Staszica, w związku z czym na Wydziale Pedagogicznym Uniwersytetu Warszawskiego odbyła się konferencja, w której uczestniczył K. Szmyd z referatem poświęconym myśli społecznej i pedagogicznej S. Staszica ${ }^{18}$.

Pracownicy Zakładu Historii Wychowania brali też udział w opracowaniu materiałów biograficznych dla słowników i encyklopedii. Jeszcze w latach 70. A. Meissner uczestniczył w pracach Zespołu badawczego dziejów oświaty w okresie okupacji hitlerowskiej PAN Oddział w Krakowie. W ramach tego zespołu koordynował pracami nad III tomem Słownika nauczycieli uczestników tajnego nauczania i ruchu oporu na terenie powojennego województwa rzeszowskiego, i opracował około 180 not biograficznych nauczycieli

\footnotetext{
${ }^{13}$ Materiały obrad tej sekcji ukazały się pt. Chtopi. Naród. Kultura, T. 4: Kultura $i$ oświata wsi, red. A. Meissner, Rzeszów 1996.

${ }^{14}$ Myśl pedagogiczna ks. Bronistawa Markiewicza. Materiały z sesji naukowej zorganizowanej 18 kwietnia 1997 r., red. prof. dr hab. J. Homplewicza i ks. dr A. Garbarza, Rzeszów 1997.

${ }^{15}$ Art. zamieszczony został $\mathrm{w}$ materiałach pokonferencyjnych pt. Stużba dziecku $w$ instytucjach siwieckich $i$ kościelnych, red. prof. J. Homplewicz i ks. A. Garbarza, Rzeszów 1998, s. 43-51.

${ }^{16}$ Materiały posesyjne pt. De rerum humanarum emendatione consultactio catholica a odkaz Jana Amosa Komenskeho pre tretie tisirocie, Bratislava 2001.

${ }^{17}$ Wielkie dzieło reformy wychowania ksiqdz Stanistaw Konarski (1700-1773). Materiały z sesji naukowej, oprac. T. Gumula, Ostrowiec Świętokrzyski 2005.

${ }^{18}$ Artykuł ukazał się w „Kwartalniku Pedagogicznym” 2006, nr 2.
} 
z terenu powiatu krośnieńskiego. Wszystkie trzy części tego Słownika obejmującego cały podziemny okręg szkolny krakowski wydał w 1995 J. Chrobaczyński. Z kolei w 1998 r. Uniwersytet Śląski w Katowicach wydał Słownik pedagogów polskich opracowany przez W. Bobrowską-Nowak i D. Dryndę, do którego pracownicy Zakładu przygotowali kilkanaście biogramów. W kolejny czterech tomach Encyklopedii pedagogicznej XXI wieku (Warszawa 2003-2006) ukazało się ponad 20 biogramów przedstawicieli nauk pedagogicznych oraz kilka haseł, takich jak: „Czasopisma pedagogiczne w Galicji”, „Encyklopedie i słowniki pedagogiczne w Polsce”, „Higiena”, „Higiena szkolna - aspekty praktyczne”, „Podręczniki do historii wychowania”, „Pedagogium”, „Seminaria nauczycielskie". Dla Słownika biograficznego historii wychowania XIX $i$ XX wieku, o czym już wspominano, opracowano około 50 biogramów. Przygotowano też kilka opracowań biograficznych dla Polskiego Stownika Biograficznego.

Należy również wspomnieć o udziale Zakładu Historii Wychowania w dyskusjach nad historią wychowania jako dyscypliną naukową i jako przedmiotem nauczycielskiej edukacji, a także udziale w rozważaniach natury metodologicznej. Niepoślednią tu rolę odegrał Cz. Majorek, który wypowiadał się o problemach metodologicznych i potrzebie nowego spojrzenia na historię wychowania, również na łamach wspomnianej już serii wydawniczej „Galicja i jej dziedzictwo” (1996, 1997). Przeglądu polskich podręczników do historii wychowania dokonał A. Meissner $(1989,2005)$, pisał także o początkach historii wychowania jako nauki $(1998,1999)$ oraz o źródłach drukowanych do dziejów oświaty w Galicji (2003). K. Szmyd zajmował się również źródłami historii wychowania w Galicji (2003) i razem z A. Krzanowskim zajął się rolą historii wychowania w kształceniu kandydatów do zawodu nauczycielskiego (1998). We współpracy z Cz. Majorkiem przygotowana została synteza dziejów oświaty w Polsce do wydawnictwa pt. International Handbook on History of Education, (red. K. Salimowa, NL Dodde, Moskwa 2000, s. 320-354; toż w języku rosyjskim pt. Pedagogika narodov mira. Istoria i sovremiennost, Moskwa 2000 s. 259-291).

Rok 2006 przyniósł zasadniczą zmianę w funkcjonowaniu Zakładu Historii Wychowania. W związku z podjętymi oszczędnościami finansowymi prof. J. Dybiec i prof. J. Szmyd nie otrzymali zgody na dalsze zatrudnienie na drugim etacie. Trudności kadrowe spowodowały, że prof. K. Szmyd został oddelegowany do kierowania innego zakładu w Instytucie Pedagogiki, chociaż na co dzień utrzymuje stałe kontakty z macierzystym Zakładem. Z tych samych powodów Zakład Historii Wychowania został połączony z Zakładem Teorii Wychowania, tworząc Zakład Historii i Teorii Wychowania. Z powodów pozamerytorycznych dr Ewa Barnaś-Baran, posiadająca doktorat $\mathrm{z}$ historii wychowania została przeniesiona do Zakładu Pedagogiki Opiekuńczej. Na emeryturę odeszli A. Meissner i A. Krzanowski. W tej sytuacji pozostało trzech historyków wychowania (prof. K. Szmyd, Dr Cz. Płaza, dr E. Dolata), co w poważny sposób ograniczy możliwości prowadzenia dalszych badań naukowych, zwłaszcza o charakterze zespołowym. Tak drastyczne zmiany kadrowe zostały również spowodowane modyfikacjami siatek studiów pedagogicznych, polegającymi na ograniczaniu zajęć, tam gdzie to uznano za możliwe, do samych wykładów. Należy mieć nadzieję, że przezwyciężenie kryzysu ekonomicznego, a co za tym idzie i kryzysu kadrowego umożliwi reaktywowanie Zakładu Historii Wychowania i przywrócenie dotąd pełnionych funkcji. 